\title{
Enigma Kejahatan dalam Sekam Filsafat Ketuhanan
}

\section{Andri Fransiskus Gultom}

Program Pascasarjana Ilmu Filsafat

Universitas Gadjah Mada, Indonesia

Email: andri.gultom@gmail.com

\begin{abstract}
Abstrak
Artikel ini membahas tentang problematika kejahatan dalam kaitannya dengan keberadaan Tuhan. Kejahatan yang kerap dihadapi manusia dalam hidup menjadi persoalan yang coba diruntut berdasar perspektif filsafat ketuhanan. Dalam artikel ini, adanya kejahatan yang terdapat di dalam sepanjang sejarah kehidupan manusia, menghadirkan pertanyaan mendasar tentang keberadaan Tuhan. Tuhan yang diyakini sebagai Yang Maha Baik dihadapkan dengan realita kejahatan dalam kontestasi ide filosofis. Terdapat empat tema pembahasan yang berawal dari pertanyaan-pertanyaan filosofis perihal relasi kejahatan dengan ketuhanan, yaitu: apa itu teodise? Apa itu kejahatan? Beranjak dari pertanyaan tersebut, penulis mendapati bahwa kejahatan merupakan suatu kenyataan yang disebut dengan enigma. Kenyataan enigmatik yang dihadapi manusia dalam kehidupan tersebut memposisikan manusia sebagai subjek yang rentan (vulnerable subject) tatkala berhadapan dengan kejahatan.
\end{abstract}

\begin{abstract}
This article discusses about the problematics of crime in relation to the existence of God. Crimes that are often faced by humans in life have been problems that try tracing based on existence of god perspective. In this article, the crimes contained in the history of human life, presents a fundamental question about the existence of God. God is believed to be the Most Good confronted with the reality of crime in the contestation of philosophical ideas. There are four discussion themes which start from the philosophical questions regarding the relationship with Divinity crime, namely: what is it theodicy? What is crime? Moving on from these questions, the authors found that the crime is a reality called the Enigma. The fact of the Enigmatic faced by humans in the life has been positioned that humans as a vulnerable subject whenthey are dealing with crime.
\end{abstract}

Keywords: Crime, Philosophy of God

Intizar, Vol. 22, No. 1, 2016 
Manusia kerap mengalami problem yang sulit diterima dengan akal sehat. Tak dapat diingkari bahwa problem seakan menjadi bagian dari realitas dari kehidupan itu sendiri. Problem menjadi problem karena ada situasi yang berjarak antara harapan dan kenyataan. Manusia berharap hidup dalam kebaikan, namun kenyataan memperlihatkan adanya kejahatan. Di hadapan kejahatan yang terjadi, manusia bingung dan lalu bertanya, di mana Tuhan?.

Kejahatan menjadi problem dalam filsafat ketuhanan justru karena problem ini membawa manusia kepada pertanyaan mendasar tentang eksistensi Allah. ${ }^{1}$ Allah yang dulu diyakini sebagai Mahabaik, Maha Pemurah, Mahaadil, Mahacinta, Mahabijaksana, kini jarang ditemukan lagi dalam pengalaman keseharian hidup manusia. Mereka kecewa dan hilang kepercayaan hingga lahir pertanyaan-pertanyaan fundamental itu. Dalam abad ke-19 David Hume coba mencuatkan pertanyaan-pertanyaan skeptis itu sebagai berikut:

“... Is God Willing to prevent evil but not able? Then God is impoten. Is God Able to prevent evil but not willing? Then God is malevolent. Is God Both willing and able to prevent evil? Then why is there any evil in this world?...,2

Deretan pertanyaan ini sekaligus menjadi tantangan bagi iman umat manusia. Memang akibatnya bisa fatal tetapi juga menjadi bahan polemik yang tidak berkesudahan. Fatal bagi yang rapuh dan bahan polemik bagi mereka yang tegar imannya. Berbagai argumen klasik mulai dari yang paling sederhana sampai yang paling rumit telah dikemukakan untuk membuktikan bahwa Allah tetap hadir dengan segala kebaikan-Nya yang sempurna di bumi ini.

Manusia disergap oleh pertanyaan eksistensial (tentang dirinya, dari mana asalnya, siapa penciptanya, dan ke mana tujuan akhir hidupnya) tatkala ia diterpa oleh problem kejahatan. Peristiwa kejahatan yang mengerikan dalam sejarah: pembantaian jutaan orang Yahudi di kamp-kamp konsentrasi Nazi, pembunuhan massal dalam perang saudara di Rwanda dan Burundi, pemerkosaan dan pembunuhan di Bosnia, peristiwa Twin Tower 11/9 di New York, perang Afganistan dan Irak yang menelan ribuan nyawa manusia, dan bencana Tsunami di Aceh dan di Nias yang meluluh-lantakkan bangunan dan ratusan ribu nyawa manusia melayang.

Problem-problem kejahatan tersebut membuat manusia berada dalam situasi cemas dan takut. Ini sungguh pengalaman akan dunia yang absurb. Kalau 
dunia diciptakan oleh Tuhan yang Maha Kuasa dan Maha Baik, sebagaimana diajarkan dan diamini oleh manusia dalam agama, lantas bagaimana bisa dimengerti ciptaanNya begitu tidak sempurna? Kalau Tuhan ada, darimanakah datangnya penderitaan? (Si Deus, unde Malum?) Jika Ia tak berdaya di hadapan kejahatan dan penderitaan, masih layakkah kita (manusia) beriman kepada-Nya?

Pertanyaan-pertanyaan seperti itu seakan menjadi problem teodise bagi kaum teis dan menjadi pijakan kokoh bagi kaum nonteis. Di hadapan kejahatan, kaum teis bisa mengambil sikap untuk berpasrah dan menerimanya sebagai takdir dan bawaan dari dosa asal. Pandangan teodise seperti ini tentunya merupakan pemahaman tradisional naturalistik di mana manusia menyerah dan merasa tidak layak untuk mempertanyakan peristiwa kejahatan yang terjadi. Sedangkan bagi kaum nonteis, adanya kejahatan menjadi kontradiksi logis karenanya eksistensi Tuhan menjadi suatu pertanyaan. Kontradiksinya, Kemahakuasaan yang melekat dalam Tuhan ternyata tidak kuasa di hadapan kejahatan. Hal inilah menjadi dasar penyangkalan akan adanya Tuhan.

Ulasan dalam makalah ini berupaya menerangi problem kejahatan dengan menggunakan kerangka filsafat ketuhanan. Masalah kejahatan menjadi objek material dan filsafat ketuhanan sebagai objek formalnya. Dalam makalah ini, ada empat pembahasan yang akan diuraikan yaitu: pertama, apa itu teodise? Kedua, apa itu kejahatan? Ketiga, penulis akan menguraikan tiga dimensi masalah kejahatan. Pada bagian keempat akan menguraikan enigma kejahatan dalam sekam filsafat ketuhanan. Bagian kelima, penulis berupaya memberi penafsiran tentang posisi manusia sebagai subjek yang rentan (vulnerable subject) tatkala berhadapan dengan kejahatan. Di bagian akhir, penulis akan menutup bahasan dengan memberikan kesimpulan dan refleksi kritis.

\section{Makna Teodise}

Teodise (theodicy) adalah istilah yang diperkenalkan oleh Leibniz yang diambil dari bahasa Yunani yaitu kata theos (Tuhan) dan dike (keadilan/kelayakan) ${ }^{3}$. Teodise merupakan suatu usaha untuk membenarkan dan mempertahankan Tuhan dalam wajah kejahatan dengan menjawab problemproblem yang paling dasar atas beberapa asumsi berikut: pertama, Tuhan adalah Maha Baik dan Maha Kuasa (dan manusia tahu); kedua: alam semesta diciptakan oleh Tuhan dan/atau ada dalam suatu hubungan kontigen pada Tuhan; ketiga, mempertanyakan keberadaan kejahatan ada dalam dunia.

Intizar, Vol. 22, No. 1, 2016 
Bria mengartikan teodise sebagai salah satu pendekatan dari kaum teis atas masalah kejahatan. Pendekatan yang lain adalah apologi (defense). Tujuan pendekatan teodise adalah untuk memberikan suatu dasar yang positif, masuk akal, dan adekuat mengenai adanya kejahatan dalam semesta pemikiran teistik. Sedangkan pendekatan yang kedua bertujuan untuk menunjukkan bahwa argumentasi nonteistik, baik secara logis maupun evidensial, menyandang cacat dari dalam bangunan argumentasi mereka sendiri ${ }^{4}$.

\section{Konsep Kejahatan}

Hal mendasar yang perlu dipahami sebelum membicarakan lebih lanjut kaitan Tuhan dan kejahatan adalah apa itu kejahatan? Kejahatan sebagaimana diacu oleh banyak penulis dalam diskusi mengenai masalah kejahatan dibagi menjadi dua bagian, yaitu kejahatan moral dan kejahatan alamiah. Kejahatan moral berupa kejahatan yang muncul dari seseorang atau beberapa pelaku yang secara sadar dan bebas melakukan tindakan yang salah secara moral, misalnya dengan bertindak secara tidak adil dan tidak jujur sehingga menyebabkan penderitaan bagi pihak lain (evil by commision). Contoh kejahatan ini antara lain pembunuhan, pemerkosaaan, pencurian, dan sebagainya.

Jenis kejahatan yang lain adalah membiarkan orang lain mengalami penderitaan atau menjadi korban kejahatan, meskipun ia dapat menolong (evil by omision). Sementara itu, kejahatan alamiah mengacu pada penderitaan yang muncul dari determinasi alamiah, seperti cacat bawaan, banjir, gempa bumi, tsunami, dan lain-lain. Jenis kejahatan terakhir ini secara inheren terkonstruksi dalam struktur biologis alam, termasuk manusia. Misalnya, tubuh secara alami berproses menuju kehancuran atau binatang menjadi korban dan pemangsa bagi yang lain.

Masalah kejahatan pada prinsipnya merupakan persoalan filsafat, karena ada kontradiksi antara adanya Tuhan dan adanya kejahatan. Teolog Hans Kung menganggap masalah kejahatan sebagai "batu karang ateisme" karena secara adekuat mempersoalkan sifat tradisional Tuhan yaitu mahakuasa (omnipotence). Sedangkan, Agustinus memfokuskan teodise pada genesis kejahatan di dunia. Tujuannya untuk membebaskan Tuhan pencipta dari kesalahan dan menekankan bahwa kejahatan berasal dari ciptaan-Nya.

Teodise menurut Agustinus yaitu pertama tidak ada sesuatu yang jahat secara esensial. Kejahatan ada dalam kebaikan sebagai subjek. Kedua, meskipun kejahatan senantiasa mengurangi kebaikan, ia tidak akan secara total 
memangsanya, tidak ada pernah ada kejahatan total, karena jika demikian, maka ia akan menghancurkan dirinya sendiri. Kebaikan tetap ada sebagai jantung segala ciptaan. Ketiga, kejahatan secara aksidental disebabkan oleh kebaikan; atau kejahatan adalah "ketiadaan kebaikan" (privatio boni). Keempat, Tuhan bukan entitas yang bertanggung jawab atas adanya kejahatan ${ }^{5}$.

\section{Tiga Dimensi Masalah Kejahatan}

Secara umum, ada tiga dimensi masalah kejahatan, yakni: pertama, dimensi logis. Masalah kejahatan dalam dimensi ini dipersoalkan dalam frame apriori oleh para kritikus teisme seperti: J. L. Mackie, H. J. McCloskey, dan Richard LaCroix. Mereka memproblematisir antara lain: pertama, adanya inkonsistensi logis antara posisi keyakinan tradisional tentang sifat Tuhan yang mahakuasa, mahatahu, dan mahabaik dengan proposisi mengenai adanya kejahatan. Kedua, apakah adanya kejahatan, walaupun dalam bentuk dan jumlah yang sedikit, secara logis bisa didamaikan dengan adanya Tuhan? Ketiga, apakah adanya Tuhan secara logis bisa didamaikan dengan adanya kejahatan yang mengerikan dan tak terpahami (gratuitous evil).

Kedua, dimensi evidensial. Dalam dimensi evidensial, masalah kejahatan (aposteriori), yang menjadi persoalan adalah apakah Tuhan itu masuk akal di hadapan kenyataan konkret adanya kejahatan? Atau kalau dirumuskan secara lebih konkret: Apakah adanya Tuhan bisa dipahami atau masuk akal dihadapan peristiwa kejahatan konkret seperti pembunuhan massal terhadap kaum Yahudi di kamp-kamp konsentrasi Nazi, peristiwa tsunami di Aceh? Itulah pertanyaan mendasar dari para kritikus teisme berkaitan dengan dimensi evidensial.

Ketiga, dimensi eksistensial. Pada dimensi eksistensial, masalah kejahatan berada dalam aspek kehidupan nyata manusia dihadapan realitas kejahatan. Persoalan mendasar dari dimensi ini mencakup bagaimana pengalaman seseorang mengenai kejahatan mengondisikan sikapnya terkait dengan Yang Ilahi dan dunia? Masalah ini tidak dapat begitu saja direduksi pada persoalan emosional atau psikologis semata, juga tidak bisa dipisahkan dari keyakinan, nilai, dan prinsip hidup seseorang.

Dimensi eksistensial dari masalah kejahatan muncul manakala pengalaman buruk mengenai kejahatan melahirkan krisis iman religius. Ivan Karamazov adalah kasus paradigmatik dari penolakan eksistensial terhadap agama teistik.

Intizar, Vol. 22, No. 1, 2016 


\section{Enigma Kejahatan dalam Sekam Filsafat Ketuhanan}

Problem kejahatan dari sudut pandang filsafat, berakar pada empat persoalan dasar. Pertama, persoalan tentang eksistensi Tuhan sebagai pencipta segala sesuatu. Kedua, persoalan tentang eksistensi kejahatan sebagai tragedi realitas. Ketiga, persoalan tentang eksistensi manusia yang bebas, sekaligus sebagai agen tanggung jawab. Keempat, persoalan tentang eksistensi alam yang dinamis dengan hukum-hukum dan perkembangannya sendiri ${ }^{6}$.

Dari keempat persoalan itu kemudian muncul pertanyaan filosofis mendasar tentang kejahatan: Darimana asal-usul kejahatan? Apakah kejahatan berdimensi transenden atau imanen? Apa kejahatan itu bersifat objektif, relatif atau relasional?

Dalam mencari solusi atas problem kejahatan salah satu tugas filsafat adalah membongkar ketidaksehatan penalaran yang mendasari argumentasiargumentasi tertentu. Filsafat menyiapkan jalan pemahaman yang lebih baik dengan alasan-alasan yang positif. Sebab, sebagai ilmu kritis, filsafat dalam mengembangkan kriteria material untuk pemahaman dan pemecahan masalah kejahatan tidak dapat membatasi diri hanya secara dogmatik pada premis-premis suatu tradisi tertentu atau pada diskusi formil inter disiplin ilmu pengetahuan.

J. L Mackie (1917-1981) menawarkan pandangan yang dikenal dengan sebutan "problem logis kejahatan" (logical problem of evil). Pada dasarnya, Mackie beranggapan bahwa klaim kaum teis mengatakan Tuhan itu mahakuasa, mahatahu, dan seutuhnya baik menjadi inkonsisten dengan adanya kejahatan di dunia. $^{7}$ Pemahaman ini menjadi bahan bagi Mackie untuk mempertanyakan kemampuan mencipta Tuhan. Tidak mungkin, Tuhan yang mahakuasa tidak mampu menciptakan alam semesta dengan kebaikan moral tapi tanpa kejahatan.

Keraguan Mackie, tampaknya terpengaruh dari pernyataan klasik dari Epikuros yang mencoba membahas hubungan antara Allah dan kejahatan. Ada empat hipotesa Epikuros ketika Allah dihadapkan pada kejahatan. Pertama, Allah mau meniadakan kejahatan, tetapi Ia tidak mampu meniadakan kejahatan. Jika demikian Allah tidak maha kuasa tetapi baik hati. Kedua, Allah mampu meniadakan kejahatan tetapi Ia tidak mau. Jika demikian, Allah itu maha kuasa tetapi buruk hati. Ketiga, Allah tidak mau dan tidak mampu meniadakan kejahatan. Jika demikian, Allah adalah buruk hati dan tidak berdaya. Keempat, Allah mampu meniadakan kejahatan dan mampu menidakan kejahatan. Jika demikian, Allah adalah baik hati dan maha kuasa. Kemungkinan keempat adalah

Intizar, Vol. 22, No. 1, 2016 
tipe Allah yang ideal, tetapi pada kenyataannya kejahatan terjadi di dunia ini, sehingga dapat disimpulkan bahwa Tuhan tidak ada. ${ }^{8}$

Teodise terkadang dimengerti sebagai enigma ${ }^{9}$ oleh kaum teis sebagai bagian dari kejahatan itu sendiri. Pandangan seperti ini tentu tidak sepenuhnya benar. Mackie berupaya menjernihkan kerancuan pandangan yang mencoba menggabungkan antara kebaikan dan kejahatan sebagai suatu keselarasan. Ia berupaya "menjaga jarak" pada pernyataan-pernyataan kaum teis yang jatuh pada simplifikasi dan adanya solusi yang keliru (fallacious solutions) tatkala kaum teis mau menjawab problem kejahatan.

Keempat enigma tersebut yaitu:

1. Kebaikan tidak akan Ada Tanpa Kejahatan atau Kejahatan Dibutuhkan untuk Mendukung Kebaikan

Pernyataan tersebut bisa dijelaskan dalam tiga uraian, yakni: pertama, pernyataan tersebut seolah-olah mau mendamaikan antara kejahatan dan kebaikan. Hal ini memberikan, menurut Mackie, memberi batas pada apa yang tidak dapat Tuhan lakukan, menyatakan bahwa Tuhan tidak dapat menciptakan kebaikan tanpa sekaligus menciptakan kejahatan ${ }^{10}$. Kedua, hal ini berarti bahwa Tuhan bukanlah mahakuasa atau ada batasan dari kemahakuasaan Tuhan. Batasan tersebut mengisyaratkan bahwa kemahakuasaan bukan berarti kuasa yang secara logis tidak mungkin. Penafsiran kemahakuasaan Tuhan itu, menurut Mackie, tentu saja diterima sebagai suatu paradoks. Ia menjelaskan demikian:

"It is, perhaps, the most common theistic view, but I think that some theists at least have maintained that God can do what is logically imposible. Many theists, at any rate, have held that logic itself is created or laid down by God, that logic is the way in which God arbitrarily chooses to think... and this account of logic is clearly inconsistent with the view that God is bound by logical necessities... when we come to the Paradox of Omnipotence.",11

Uraian yang ketiga, dalam pandangan Mackie, bahwa solusi tersebut menolak bahwa kejahatan adalah lawan kebaikan dalam arti sebenarnya. Jika kebaikan dan kejahatan saling mendukung mestinya hal-hal yang baik tidak akan mengeliminasi kejahatan. Tentu saja pandangan ini menyarankan bahwa kebaikan dan kejahatan tidak bisa diterapkan atau diberlakukan pada semua hal.

2. Kejahatan merupakan Kebutuhan untuk Mengartikan Kebaikan.

Penjelasan ini sangat simplistik, karena menolak yang satu dan menerima yang lain, atau menerima kontradiksi secara bersamaan. Pernyataan tersebut

Intizar, Vol. 22, No. 1, 2016 
sangat bisa dipahami dalam paradigma hukum kausal naturalistik bahwa manusia memerlukan kejahatan sebagai lawan untuk menjadikan kebaikan menjadi teman. Dengan demikian, kejahatan bisa menyebabkan atau menimbulkan adanya kebaikan. Tentu pernyataan ini bisa menjadi sebuah jawaban yang keliru, karena problem kejahatan hanya dijelaskan dengan upaya berdamai-damai melalui logika oposisi biner, lawan menjadi kawan.

\section{Alam Semesta Menjadi Lebih Baik dengan Adanya Beberapa Kejahatan di dalamnya daripada Jika tidak ada Kejahatan}

Kejahatan punya kontribusi pada kebaikan. Suatu analogi estetik. Pernyataan solusif seperti itu biasanya mulai dari asumsi bahwa kejahatan muncul dari yang biasa disebut kejahatan secara fisik (sakit). Dalam pandangan Hume, problem kejahatan mencakup pada sakit dan penderitaan yang menimbulkan adanya rasa simpati, kebajikan, heroisme, dan perjuangan dokter dan para pembaharu untuk mengatasi kejahatan. Dalam kenyataan, kaum teis mengambil kesempatan bagi mereka yang sakit dan menderita dengan menuding bahwa kejahatan sebagai perjuangan untuk mencapai kebaikan.

\section{Kejahatan adalah Kehendak Bebas Manusia}

Solusi yang tampaknya cukup logis ketika kejahatan tidak untuk menyalahkan Tuhan, tetapi pada kehendak bebas manusia. Pernyataan ini mau menyelamatkan Tuhan dari tudingan bahwa dengan kemakuasaannya, Ia juga menciptakan kebaikan sekaligus juga kejahatan. Pandangan ini mengatakan bahwa Tuhan tidak bertanggung jawab pada independensi manusia yaitu kehendak bebas. Pernyataan ini juga bukan solusi yang memuaskan, bagi Mackie, karena terdapat inkoherensi dari ide kebebasan kehendak dengan dari mana kehendak manusia itu berasal dan mengapa Tuhan menciptakan kehendak bebas? Suatu pandangan yang terkadang absurb, karena pembuatan pilihan yang keliru secara logis penting bagi kebebasan, jadi kelihatan bahwa kebebasan di sini berarti kebebasaan ditentukan oleh suatu karakter tertentu.

\section{Manusia: Subjek yang Rentan (Vulnerable Subject) di Hadapan Kejahatan}

Berhadapan dengan kejahatan, manusia cenderung gampang rentan (sakit, terluka, dan cedera). Sebuah kajian psikologis mutakhir, yang dimuat dalam edisi perdana jurnal Clinical Psychological Science, menunjukkan bahwa manusia yang mengalami kerentanan (dalam hal ini kognitif) bisa menularkan kerentanan 
tersebut ke orang-orang lain yang ada di sekitar. ${ }^{12}$ Kerentanan kognitif itu, menurut Ioanes Rahmat, bisa dijelaskan sebagai berikut: jika anda tinggal sekamar dalam waktu panjang dengan orang yang tingkat kerentanan kognitifnya tinggi, anda akhirnya juga akan terserang depresi. Jika teman-teman bergaul anda orangorang yang selalu murung dan negatif dalam memandang diri dan kehidupan mereka, kondisi mental ini akan tertular ke anda. Begitu juga, jika orang-orang fundamentalis yang selalu negatif dalam memandang realitas dunia tak pernah keluar dari komunitas mereka. Mereka akan selamanya fundamentalis dengan tingkat "kerentanan kognitif" yang kian tinggi. Sekali lagi harus ditekankan, orang fundamentalis umumnya adalah orang dengan tingkat "kerentanan kognitif" yang tinggi. Begitu juga, seorang beragama yang selalu memandang dirinya penuh dosa dan sedang terkena murka Allah, juga hidup dengan tingkat "kerentanan kognitif" yang tinggi.

Ada pandangan yang menarik (dan perlu dibahas), bagi penulis tatkala orang beragama (teis) pun memungkinkan berada dalam kerentanan (bukan hanya kognisi, tetapi afeksi atau psikisnya juga dan bisa berdampak pada tindakannya, (penulis) saat berhadapan dengan kejahatan. Secara kognisi, mengikuti pandangan psikologis di atas, kerentanan itu membuat kaum teis terjebak dalam sekam enigma yang tradisional, yaitu cara pikir mereka "ikut tertular" bahwa kejahatan itu adalah bagian dari rencana atau cobaan Tuhan.

Kejahatan membuat manusia rentan secara afeksi yaitu jiwanya merasa takut, gemetar, dan resah. Di balik kejahatan pada dasarnya tersirat ketidakmampuan jiwa manusia untuk mengalami peristiwa-peristiwa negatif (moment of negativa) seperti: penderitaan, depresi, sedih, luka batin, kecewa, duka, dan sebagainya. Namun, bukan berarti moment of negativa tersebut melemahkan diri manusia. Tetapi malah mengantarkan manusia pada eksistensi sesungguhnya, di mana ia bisa menemukan ada kekuatan lain yang lebih besar dari kemanusiaannya dan kejiwaannya.

Pada tahap tindakan, kejahatan merentankan manusia pada pertarungan materi yang seolah tiada habisnya. Manusia yang ditimpa kejahatan bisa melakukan tindakan yang brutal. Pernyataan semacam ini, mengikuti Karlina Supelli bahwa kerentanan juga perkara hubungan antara cuaca kultural kita dan brutalitas pertarungan materi yang menandai sejarah dewasa kini. Dalam pertarungan itu, kerentanan merupakan potret buram tata sosial, ekonomi, dan politik, yang cirinya adalah kesenjangan akses. ${ }^{13}$ Dalam pandangan ini, bagi Karlina Supelli, kerentanan manusia berkaitan dengan peran negara. Manusia 
sebagai warga negara diabaikan, dan para pengelola negeri alpa dan tidak peduli dengan situasi riil warganya.

Kerentanan manusia dihadapan kejahatan bukan hanya perkara ketiadaan daya ketika malapetaka menimpa. Kerentanan terutama berisi ketiadaan kebebasan ke berbagai sumber daya yang menyangga seseorang agar berkemampuan sebagai manusia. Atau, percaya bahwa kelompok paling rentan pun mampu menghidupkan kembali harapan dan gugus penyangga untuk hidup di dunia.

\section{Kesimpulan}

Kejahatan menjadi problem filsafat justru karena problem ini membawa manusia kepada pertanyaan mendasar tentang eksistensi Tuhan. Tuhan yang dulu diyakini sebagai Mahabaik, Maha Pemurah, Mahaadil, Mahacinta, Mahabijaksana, kini jarang ditemukan lagi dalam pengalaman keseharian hidup manusia. Mereka kecewa dan hilang kepercayaan hingga lahir pertanyaan-pertanyaan fundamental itu.

Kejahatan adalah suatu fakta hidup yang terkadang tidak mudah untuk dipahami. Kejahatan seolah bersembunyi dalam sekam, dan filsafat berfungsi untuk mencari sekaligus menemukan titik primodial dari problem kejahatan itu. Upaya filsafat dilakukan dengan mengkritisi simplisitas pernyataan-pernyataan yang berupaya menjawab kemahakuasaan Tuhan dalam menghadapi kejahatan. Di sini, filsafat mengajak manusia untuk sampai pada eksistensi hidupnya. Kejahatan dipandang sebagai suatu fenomena yang mengisyaratkan adanya enigma yang tersembunyi untuk menimbulkan suatu tanya bahwa ada kekuatan di luar wilayah rasional manusia. 


\section{Endnote}

${ }^{1}$ Joseph A. Komonchak, The New Dictionary of Theology, (Philippine: Saint Paul Publication, 1991), hlm. 360

${ }^{2}$ Ibid.,

${ }^{3}$ http://philosophy.lander.edu/intro/hick.html diakses 1/10/2013

4 Emanuel Bria, Jika Ada Tuhan Mengapa Ada Kejahatan, Percikan Filsafat Whitehead, (Yogyakarta: Kanisius, 2008), hlm. 47

${ }^{5}$ Ibid., hlm. 52

${ }^{6}$ R. W. Kopt, Evil and Evolution, (England: Associated University Press, 1983),

${ }^{7}$ J. L. Mackie, Evil and Omnipotence, dalam buku Philosophy of Religion Selected Readings (Third Edition) edited by Michael Peterson, (New York: Oxford University Press, 2007), hlm. 304. Teks aslinya: "Essentially, he argues that the theistic claim that God is omnipotence, omniscient, and wholly good is inconsistent with the theistic claim that there is evil in the world"

${ }^{8}$ Louis S. J. Leahy, Filsafat Ketuhanan Kontemporer, (Yogyakarta: Kanisius, 1993), hlm. 271

${ }^{9}$ Enigma yang dimaksud dalam konteks ini adalah pernyataan-pernyataan yang membingungkan atau memuat teka-teki.

${ }^{10}$ J. L. Mackie, Evil ..., Op.Cit., hlm. 307

${ }^{11}$ Ibid,

12 Ioanes Rahmat, 2003. Kerentanan Kognitif dalam http://ioanesrakhmat.blogspot.com/2013/04/kerentanan-kognitif.html diakses 28/09/2013. Review atas kajian ini (18 April 2013) tersedia online di laman ini http://www.psychologicalscience.org/index.php/news/releases/risk-factor-for-depressioncan-be-contagious.html

${ }^{13}$ Karlina. Supelli, 2007. "Republik Alpa" dalam harian Kompas 31/12/2007 dalam http://kompas.com/kompas-cetak/0712/31/utama/4113143.htm diakses 27/09/2013

\section{Daftar Pustaka}

Bria, Emanuel. (2008). Jika Ada Tuhan Mengapa Ada Kejahatan, Percikan Filsafat Whitehead. Yogyakarta: Kanisius.

Komonchak, Joseph, A. (1991). The New Dictionary of Theology. Philippine: Saint Paul Publication.

Kopt, R. W. (1983). Evil and Evolution. England: Associated University Press.

Kuswanjono, Arqom. (2006). Ketuhanan dalam Telaah Filsafat Perenial, Refleksi Pluralisme Agama di Indonesia. Yogyakarta: Badan Penerbitan Filsafat UGM.

Leahy, Louis S. J. (1993). Filsafat Ketuhanan Kontemporer. Yogyakarta: Kanisius. 
Mackie, J. L. (2007). Evil and Omnipotence, dalam buku Philosophy of Religion Selected Readings (Third Edition) edited by Peterson, Michael. New York: Oxford University Press.

Rahmat, Ioanes. (2003). Kerentanan Kognitif dalam http://ioanesrakhmat.blogspot.com/2013/04/kerentanan-kognitif.html diakses 28/09/2013

Supelli, Karlina. (2007). Republik Alpa dalam harian Kompas 31/12/2007 dalam http://kompas.com/kompas-cetak/0712/31/utama/4113143.htm diakses 27/09/2013

Theodicy: An Overview dalam http://philosophy.lander.edu/intro/hick.html diakses 1/10/2013 